\title{
Watergate: Next Time, Will We Be So Lucky?
}

Watergate and the Constitution. By Philip B. Kurland. Chicago: University of Chicago Press, 1978. Pp. x, 261. \$12.50.

\section{Reviewed by Philip A. Lacovara ${ }^{\dagger}$}

Two weeks after a unanimous Supreme Court ordered Richard Nixon to honor a trial subpoena issued by the Special Prosecutor in the Watergate cover-up case, ${ }^{1}$ President Nixon became the first President in American history to resign from office. The disclosure of the "smoking gun" tape, which demonstrated the President's active complicity in the cover-up conspiracy from virtually the first moment, had eroded all but the most fanatical Nixon support in Congress. The President had been left facing the almost certain prospect of impeachment by the House ${ }^{2}$ on the three articles of impeachment approved by the Judiciary Committee. ${ }^{3}$ Although the eventual outcome of a possible trial in the Senate was somewhat less certain, there was no doubt that the trial would be a lengthy, tortured affair further immobilizing the conduct of the national government. The President's resignation, therefore, was greeted by an audible sigh of relief around the country. ${ }^{*}$ With a combination of smugness and elation, politicians, journalists, and lawyers promptly proclaimed: "Our system works."

In contrast, Professor Philip B. Kurland's new book, Watergate and the Constitution, ${ }^{6}$ argues that the Watergate episode demonstrates that our governmental system, in its present form, does not work. ${ }^{7}$

+ Member, New York and District of Columbia Bars; formerly Counsel to the Special Prosecutor, Watergate Special Prosecution Force.

1. United States v. Nixon, 418 U.S. 683 (1974).

2. See 3 W Watergate and the White House 230-31 (1974) (E. Knappman \&. E. Drossman eds.) [hereinafter cited as WATERGATE 3].

3. See generally House Comm. on the Jldiciary, IMPEachment of Richard M. Nixon, President of the United States, H.R. Rrp. No. 1305, 93d Cong., 2d Sess. (1974) [hereinafter cited as IMPEACHMENT REPORT].

4. See WITERGate 3, supra note 2, at 226.

5. See, e.g., IMPEAchmeNt RePORT, supra note 3, at 319-20 (statement of Rep. Rangel); L. Jaworshi, The Right ANd The Power 279 (1976).

6. P. Klrland, Watergate and the Constitution (1978) [hereinafter cited by page number only].

7. Kurland notes initially that " $[\mathrm{t}]$ he notion that because we have come through one critical period we have been restored to health is more wish than reality. Perhaps we 
Kurland identifies the root problem of Watergate as the differences between our current governmental system and that envisioned in the Constitution. ${ }^{8} \mathrm{He}$ contends that there were "two distortions of constitutional government revealed by Watergate": ${ }^{0}$ a shift in the balance of power from Congress to the executive branch, and the rise within the executive branch of an inordinately powerful White House staff. ${ }^{10} \mathrm{He}$ attributes the Watergate abuses to these institutional weaknesses, ${ }^{11}$ and concludes that, after Watergate, no "reforms" have dealt with them. ${ }^{12}$

In seeking the major lesson of Watergate, Kurland comes to the right conclusion for the wrong reasons. Watergate did indeed demonstrate fundamental defects in our governmental system, but they are not the defects that Kurland suggests. Kurland confronts the inevitable when he assails the rise of a powerful executive branch, and misses the real lesson of Watergate when he fails to discuss the inadequacy of the means available for controlling abuses of power -specifically the lack of a viable impeachment mechanism. These defects in Kurland's analysis in turn stem from a pervasive fallacy in his work: the assumption that the causes of Watergate were exclusively institutional. Finally, because he misperceives the causes of Watergate, Kurland underestimates the value of some of the reforms that have emerged, although his sense that the largest problems remain unremedied is correct.

\section{The Lesson of Watergate: Our System Does Not Work}

Although Kurland accurately perceives that Watergate demonstrates fundamental failures in our governmental system, his development of that theme is ultimately inadequate. Kurland concentrates his

have removed a cancerous growth that could have killed us. We have not rid the system of the disease." P. 4. Kurland goes on to state that "[t]he constitutional crisis of Watergate ... was the result of the failure to adhere to the limitations on authority that are explicit and implicit in the Constitution." P. 5. He places considerable blame on the courts, discussing at some length the process of "constitutional amendment" by the judiciary, see pp. 8-16, and the role of the courts in making " $t]$ he separation of powers as a doctrine restraining the exercise of power by the executive branch . . . all but disappea[r]." P. 176.

8. Pp. 7-10, 157-63, 214-15; see p. 166 ("We are governed today by a constitution far different from that which Washington bequeathed to us. And the most basic changes have been brought about by means other than constitutional amendment . . . .")

9. P. 198.

10. Id. Kurland also spends considerable time assailing the judiciary and its role in contributing to the shift in power to the executive branch. See, e.g., pp. 6-16, 53-74.

11. See, e.g., pp. 4, 170-72, 181.

12. Pp. 183, 198-99. 
attention on the causes of Watergate and the lack of significant post-Watergate reforms, arguing in effect that another "Watergate" could occur just as easily today as the first one did. ${ }^{13}$ Kurland fails, however, to address the particular resolution of the Watergate crisis, which, he seems to agree, was a successful one. ${ }^{14}$ Without establishing the fortuitous nature of the unraveling of the conspiracy and the displacement of the guilty from government, Kurland cannot establish that the next Watergate, even if just as likely to come, will not be just as successfully concluded. Those who proclaim that Watergate proves that our system works really claim nothing more.

Moreover, Kurland fails to present a convincing analysis of the ineffectiveness of our governmental system because he confuses his readers, and perhaps also himself, by using the single term "Watergate" to refer to various aspects of a complex of issues. In making his observations on "Watergate," Kurland fails to distinguish the original conspiracy within the executive branch from the initial responses of each of the three branches to the various executive transgressions, and the long-term reforms that have, or have not, resulted. ${ }^{15}$ Clearly, different structural defects in our system may be reflected by each of these. ${ }^{16}$ Although Kurland should, of course, be granted some license to use the catchword "Watergate" when his meaning is clear from context, his careless use of that slippery term blurs some of his arguments. Kurland's failure to treat the analytically distinct aspects of the complex Watergate episode in a systematic manner seriously flaws this book. ${ }^{17}$

Kurland's case is easy to make. Clearly, the Watergate episode revealed a multitude of defects in our governmental system. The very fact that the original conspiracy evolved and was implemented reflects serious institutional weaknesses. Those who claim that Water-

13. See, e.g., pp. 4-5, 224.

14. See pp. 4, 181-82.

15. See, e.5., pp. 2-6, 172, $201-02$.

16. The fact that the President and his aides responded to the Watergate break-in by initiating a massive cover-up may well indicate a more serious governmental breakdown than that which Ied to the burglary itself. Similarly, the fact that Congress's immediate response to the break-in was so limited may reflect a different inadequacy from that dcmonstrated by the difficulties experienced in conducting the impeachment hearings themselves, once those hearings were finally initiated. Finally, the fact that no truly radical reform has come about-for example, reform of the impeachment mechanism itself-may reflect yet another shortcoming in our system.

17. At the outset of the book, Kurland indicates his intent not to deal with "one of the issues posed by Watergate"-the problem of "how to bring down the powerful leader who abused his authority"-and to address instead the issue "[h]ow does one prevent the accession to such power by the just and the runjust alike?" P. 3. In thus limiting the scope of his analysis, Kurland seriously limits its usefulness, for he chooses to ignore some of the most serious problems that Watergate revealed. 
gate proves our system works readily admit this, but point to the successful exposure of the conspiracy and purge of the conspirators as evidence of compensating checks that are built into the system. ${ }^{18}$ The responses of the three branches to the original conspiracy, however, were anything but reassuring. Most alarming, perhaps, were the failures of Congress. Congress was slow to initiate investigations in the first place and slow to conduct them once they were initiated. ${ }^{10}$ Moreover, Congress seemed almost incapable of taking the necessary remedial steps once the guilt of the President became evident.

The fact that the discovery of the Watergate conspiracies and the displacement of the guilty from government was largely fortuitous is equally evident. In a real sense, the Watergate conspiracy unraveled, not because of the Constitution, but in spite of it. Kurland identifies some of these ironies, but misses others. It was the tenacity of a single federal judge, John J. Sirica, that caused the first conspirator to crack. Sensing a larger plot, Judge Sirica used one of the few weapons available to federal judges, the sentencing power, to exert decisive pressure on the conspirators. Few other district judges would have pushed the point as vigorously as Judge Sirica did, and it was his persistent commitment, rather than any formal constitutional procedures, that first broke through the conspiracy. ${ }^{20}$

18. See, e.g., H. Commager, The Defeat of America: Presidential Power and the National Character 153-58 (1976).

19. The first significant congressional action in response to Watergate came on October 3, 1972, when the House Banking and Currency Committee rejected a proposal by Chairman Wright Patman to probe possible violations of banking laws in connection with the break-in and possible campaign finance irregularities by the Republican Party. See 1 Watergate AND the Whire House 14 (E. Knappman ed. 1973). With the single execption of Senator Edward Kennedy's short-lived Judiciary Subcommittee study, see id. at 20, no congressional hearings on Watergate were conducted until mid-May 1973, almost a full year after the Watergate break-in, when those of the Senate Select Committee began. See id. at 51 (hearings began May 17, 1973); cf. H. REP. No. 453, 93d Cong., 1st Sess. 2 (1973) (Special House Subcommittee on Intelligence commenced hearings limited to possible CIA involvement in Watergate and Ellsberg matters six days earlier on May 11, 1973). The Senate Committee took well over a year to conclude its inquiry: it did not issue its final report until July 13,1974 . See WATERGATE 3 , supra note 2, at 185.

20. Whether Judge Sirica exceeded his constitutional power in using his judicial office to compel cooperation in a criminal investigation is an intriguing question. One of the dramatic ironies of Watergate was the necessity of relying on constitutionally problematic means in order to break through the conspiracies and bring the guilty to justice. Perhaps even more troubling than Sirica's action was the fact that the various investigators relied so heavily on the so-called "use immunity" statute, 18 U.S.C. $\$ \S 6001-6005$ (1976). See, e.g., Application of the United States Senate Select Comm. on Presidential Campaign Activities, 361 F. Supp. 1270 (D.D.C. 1973) (seeking immunity for testimony of Jeb Magruder and John Dean). Although the constitutionality of the use immunity statute has been upheld, see Kastigar v. United States, 406 U.S. 441 (1972), it is nonetheless disquicting to realize that encroachment on the Fifth Amendment privilege against self-incrimination was essential to the unfolding of the cover-up conspiracy. 
Several commentators have pointed to the string of fortuitous events that led to the exposure of the Watergate conspiracies: ${ }^{21}$ the peculiar presidential decision to install an extensive recording system, the uncharacteristic failure to deactivate it during the conspiratorial discussions, and the chance discovery of the existence of the tapes through the speculative questioning of a minor White House aide by a junior congressional staffer. Of course, one can only guess as to the exact course the Watergate investigation would have taken had no tapes existed or more been destroyed, but the fundamental importance of that evidence in leading to the Nixon resignation can scarcely be disputed.

Similarly, President Nixon's departure from office was not, ultimately, the result of the constitutional process of impeachment and conviction, ${ }^{22}$ or even of the Supreme Court's decision that his constitutionally based claim of "executive privilege" had to yield to the imperatives of a fair trial in the Watergate cover-up case. ${ }^{23}$ Rather, the decision to release the "smoking gun" tape of June 23, 1972 at the critical phase of the impeachment process was one that was forced on President Nixon by the resolve of his top aides. ${ }^{24}$ Under the procedures specified by the Supreme Court in the Nixon Tapes Case, ${ }^{25}$ it would have been possible for the President and his lawyers to have delayed the actual disclosure of any of the subpoenaed tapes for months or perhaps years. During that time, in the absence of the most damning evidence, President Nixon's defense against impeachment by the House, and certainly his defense against conviction and removal after a Senate trial, would have stood a substantial chance of success. ${ }^{26}$

Moreover, even the massive public and congressional reaction to the release of the "smoking gun" tape was not, by itself, enough to lead to the resignation of President Nixon. It took the combined

21. See, e.g., IMPEAchMent REPoRT, supra note 3, at 296 (statement of Rep. Conyers) ("It has frequently been argued ... that [the House impeachment] inquiry and the President's subsequent resignation demonstrate that 'the system works.' But such satisfaction or complacency is misguided. ... If the system has worked, it has worked by accident and good fortune."); C. MEe, A Visit to Haldeman and Other States of Mind 18-19 (1977); B. Woodward \& C. Bernstein, The Final Days (1976).

22. See U.S. Const. art. I, \$ 2, cl. 5 \& \$ 3, cls. 6-7, art. II, $\$ 4$.

23. See United States v. Nixon, 418 U.S. 683 (1974). The major circuit court opinion in the Watergate cover-up case is United States v. Haldeman, 559 F.2d 31 (D.C. Cir. 1976), cert. denied, 431 U.S. 933 (1977).

24. See J. Doyle, Not Arove the Law $343-44$ (1977); B. Woodward \& C. Bernstein, supra note 21 , at 323.25 .

25. United States v. Nixon, 418 U.S. 683, 714-16 (1974) (providing for in camera inspection and editing of subpoenaed material by district court).

26. See IMPEACHMENT RePORT, supra note 3, at $359 \cdot 60$ (minority report). 
efforts of virtually all of Nixon's top aides to convince him to resign, and even then Nixon came perilously close to refusing their urgings ${ }^{27}$ and insisting on "stick[ing] it out." 28

Although Kurland believes that our current governmental system does not work, he is convinced that our constitutional system, at least as originally envisioned by the framers, would work, if only given a chance. ${ }^{29}$ Kurland views the major cause of Watergate as the shift in the balance of power from Congress to the executive branch, a shift he blames in part on the long years of informal constitutional amendment by judicial interpretation, ${ }^{30}$ and in part on congressional abdication and presidential domination or usurpation. ${ }^{31}$

Kurland is undoubtedly right in suggesting that unchecked accretion of power in the executive branch led to the original abuses of Watergate. He is also correct to point to the disinclination of Congress to assert itself as leading to the original congressional failure to initiate investigations and to the subsequent inability to pursue them expeditiously. And he is right in asserting that court decisions denying Congress the information it needed for its investigations contributed to Congress's inordinate difficulty in conducting its investigations. However, in stopping here, Kurland stops short, for these points address only the difficulties of unraveling the two conspiracies, the original conspiracy and the cover-up. Kurland completely overlooks the principal constitutional deficiency illustrated by Watergate: the inability of Congress to move effectively to remedy the crisis once the conspiracies had become evident. It is particularly ironic that Kurland, with his emphasis on the system of checks and balances and their demonstrable failure in the Watergate affair, omits any discussion of the inadequacy of the impeachment mechanism. This is even more startling in light of Kurland's own admission that impeachment was originally intended as the "primary" congressional check on the executive. ${ }^{32}$

Watergate in fact demonstrated that the very constitutional process provided for dealing with a miscreant President may be the best defense he has. The process of impeaching Nixon was initiated in October 1973, after the so-called "Saturday Night Massacre," and the

27. See B. WOOdWARD \& C. BERNSTEIN, supra note 21 , at 322-60, 376-87.

28. Id. at 376.

29. See p. 5 (Watergate resulted from failure to adhere to constitutional limitations on authority).

30. Pp. 6.15, 163; see p. 8 ("[T] $]$ he process of amending the Constitution has not been confined to the formal amendment processes ....")

31. See p. 172.

32. P. 164 . 
organized investigation began the following February. By the time the President resigned in August 1974, the accumulation of evidence itself had consumed six months, and the process was still at the Committee stage. Floor debates in the House and a Senate trial, once begun, would have consumed many months, thus carrying President Nixon toward the close of his term in any event.

During that process, of course, both the Congress and the President would have been virtually incapable of dealing with any other national problem. The almost total paralysis of the national government in the period immediately preceding Nixon's resignation has been vividly described in The Final Days. ${ }^{33}$ Watergate had become almost a full-time obsession with the President and his top aides, and the conduct of domestic government and foreign relations was at a virtual standstill. ${ }^{34}$ The President's position had been seriously compromised, not just with respect to congressional leaders, but with respect to foreign heads of state as well. ${ }^{35}$ The prospect of such a situation continuing had Nixon decided to "stick it out" is not a comfortable one.

A system like the impeachment mechanism may have been adequate in 1787, when America was a simple agrarian society, when it took several weeks to span the Atlantic, and when a national government could literally assemble in the parlor of a rooming house. Two centuries later, however, the complexity of international and domestic affairs no longer permitted the luxury of impeachment. Apparently concluding, among other things," ${ }^{36}$ that it was not in the "national interest" to allow the President and the Congress to pursue the con-

33. B. WoOdWARd \& C. BERNSTEIN, supra note 21.

34. See, e.g., Newsweek, Mar. 18, 1974, at 26. Special Prosecutor Jaworski concluded, based on his conversations with General Haig and his review of the White House tapes, that President Nixon was so "enmeshed in Watergate . . that he apparently had few hours left for regular business." L. JAworsk1, supra note 5, at 136-37; see id. at 271-72.

35. See NewsweEk, supra note 34, at 26. Moreover, after the release of the "smoking gun" tape on August 5, 1974, the President's incapacity to govern became even more severe. As the President himself stated in his resignation speech on August 8, 1974:

[B]ecause of the Watergate matter I might not have the support of the Congress that I would consider necessary to back the very difficult decisions and carry out the duties of this office in the way the interests of the nation will require.

....

... America needs a full-time President and a full-time Congress . . . .

... To continue to fight through the months ahead for my personal vindication would almost totally absorb the time and attention of both the president and the Congress .....

President's Address of August 8, 1974, 1974 Pub. Papers 626.

36. Nixon's aides were also motivated during this period by partisan concerns. See, e.g., B. Woonward \& C. Bernstein, supra note 21, at 327 (aides favored release of June 23 tape because "President could not sabotage his supporters with any more nasty surprises" and because "issue was no longer the fate of one President, but of the Republican Party"). 
stitutional process of impeachment, President Nixon's closest aides made the judgment that the President could no longer demand that his adversaries follow the procedure established by the Constitution. It was they who insisted that the fatal evidence be disclosed immediately, thus further damaging the President's credibility-even with his congressional defenders-and making prompt resignation a real possibility. As one commentator has noted, however, "Republics are not saved when their ... salvation depends on the accidents of a tape recording machine and the wits of a four-star general." ${ }^{37}$ If we are ever to take any comfort in our system, some reform of the impeachment mechanism is essential.

\section{The Causes of Watergate: Personal or Institutional?}

Although the complementary processes of congressional abdication and presidential domination played a role in Watergate, Kurland drastically exaggerates their importance. These shifts in the relationships between the political branches, earlier described in Arthur Schlesinger's The Imperial Presidency, ${ }^{38}$ certainly helped to make Watergate possible. For one thing, these developments undoubtedly fueled the inherently dangerous notion that the President's unique selection by national referendum makes him the embodiment of the national will. Under that notion, any program, policy, or initiative envisioned by the President is inherently in the "national interest," and any organized opposition is automatically an antidemocratic threat to "national security." Moreover, the largely unchecked accretion of power in the White House made possible a second development: the growth of a large and powerful White House staff, a cadre of faceless "assistant Presidents" lacking any personal political base and immune to regular congressional oversight. Kurland correctly identifies the rise of this "fourth branch" of government as a major source of potential abuse, apart from, and in addition to, the general shift of power from Congress to the executive branch. Kurland's commentary goes astray, however, in dismissing the personal element in Watergate $^{39}$ After devoting some attention to prior instances of presidential overreaching by Nixon's predecessors, ${ }^{40}$ Kurland then minimizes Nixon's full culpability:

37. C. MEE, supra note 21, at 18-19.

38. A. Schlesinger, The Imperial Presidency (1973).

39. See, e.g., p. 153 ("The primary evil revealed by the events of Watergate was the presidency: not the man but the office.")

40. Pp. 210-19. 
Watergate

Nixon revealed not a capacity for innovation but only a capacity for imitation. What he did . . . was to utilize devices created by predecessors, who used them sparingly, while he used them persistently; who used them in isolation, while he used them in combination; who used them unsuccessfully, while he used them successfully, until they failed him in the end.41

It is fundamentally wrong, however, to assert that Watergate was simply the logical extension of previously institutionalized precedents. Existing institutions and attitudes may have provided a medium for Watergate, but the personal character of the participants was the essential catalyst. In the Watergate episode, the assumption that a President and his White House cadre are anointed with a popular mission was reinforced by the absence of any detectable sense of public morality on the part of the President and his key staff aides.42 As a result, once the pointless and reckless escapade at the Democratic National Committee's Watergate headquarters misfired in June 1972, a relentless logic overwhelmed the White House: the President's political survival was of supreme importance to the Nation, and any measures to preserve his status and stature became legitimate.

In focusing exclusively on the institutional causes of Watergate, Kurland forces the facts to make Watergate fit his conception of the flaws in our constitutional system. Kurland's theme is hardly surprising to anyone who is familiar with his constitutional philosophy. ${ }^{43}$ A former law clerk to Justice Felix Frankfurter, Kurland is now perhaps the leading academic exponent of the philosophy that the constitutional plan of the framers demands restraint by the judiciary, restriction of the executive, and deference to the legislature. Kurland attributes many social and political problems-including, in this latest volume, Watergate-to the steady erosion of this plan. Kurland's thesis is that to secure liberty and democracy it is necessary both to divide powers between the national government and the states and to separate and mix powers among three branches of the national government. In Kurland's view:

The constitutional crisis of Watergate was the result of a long buildup of concentrated governmental power. It was the result of the failure to adhere to the limitations on authority that are explicit and implicit in the Constitution. It was the result of long

41. P. 219 (citation omitted).

42. This expedient amorality is graphically depicted by John Dean, President Nixon's White House counsel, in Blind Ambition. See J. DEAN, BLind Ambrtion (1976).

43. See, e.g., P. Kurland, Politics, the Constitution, and The Warren Court (1970). 
denial of institutional values in favor of temporary political expediency. The tragedy of Watergate lies not in the pitiful character of the man exiled from the White House; it lies rather in the continued failure of the nation to take steps first to cabin and then to dissipate that accumulated power, the failure to revive our constitutional notions of limitations on authority. The flow to the government of power over the lives of Americans has been at flood tide for generations. There is still no sign of ebbing. ${ }^{44}$

Kurland evidently subscribes to Lord Acton's oft-repeated claim that power corrupts, and absolute power corrupts absolutely. He quotes lines from Shelley that, he suggests, "anticipated" the constitutional crisis of Watergate: ${ }^{4 \sigma}$ " 'Power, like a desolating pestilence, Pollutes whate'er it touches. " 46 In attempting to support this gloomy appraisal of the American constitutional system, Kurland unfortunately exhibits the license that is appropriate for an essayist or satirist, but not for a constitutional scholar or political historian. That two centuries of independence have witnessed a steady secular growth of national power can scarcely be denied. Nor is it possible to deny that great power may be used to threaten liberty. But it need not always be.

It is of course prudent to be vigilant in monitoring the officials to whom governmental power is entrusted, and to cabin those powers when necessary. Yet Kurland's analysis is deficient because it yearns for simpler days of weaker, diffused government, but does not address the feasibility of such retrenchment. While highlighting the risks of concentrated government, he nowhere suggests how "weaker" government can effectively or responsibly cope with the complex demands of an industrial, interdependent world. We may share Kurland's nostalgia, and recognize the germ of wisdom in his message, but we are entitled to something more.

Kurland's emphasis on redesigning or, as he would put it, reviving, our system of governance is unfortunately one-dimensional. Politicians, as was recently illustrated by Jimmy Carter's successful campaign for the Presidency, tend to stress human virtue and morality as the ultimate ingredient in good government. Academics tend to go to the opposite extreme and stress institutions or metaphysical systems. What Watergate illustrates, however, is that neither of these

44. P. 5 .

45. Id.

46. Id. (quoting P. Shelley, Queen Mab, in The Complete Poeticat Works of Percy Bysshe Syelley 252 (N. Rogers ed. 1972)). 
two views is entirely accurate. Institutional systems can be important in deterring or correcting abuses of power. Yet the concentration of considerable power is inherent in modern government, and, regrettably, there is a natural tendency for that power to be abused. In part, the ability to restrain these tendencies depends on the ready availability of a successful mechanism to control the power. Of equal importance, however, is the careful choice of leaders with sound judgment and constitutional sensitivity. What makes Watergate unique in our history is that the American people twice elected-the second time, by an unprecedented margin ${ }^{4 i}-\mathrm{a}$ man firmly believed by millions of voters to be basically dishonest. ${ }^{48}$ In a sense, therefore, the greatest constitutional failure in Watergate was the failure of the electoral process to entrust the intense powers decried by Kurland to a more reliable President.

\section{Post-Watergate Reforms}

Turning to post-Watergate reforms, Kurland finds the scene bleak. $\mathrm{He}$ discerns no major structural changes reallocating presidential powers. ${ }^{49} \mathrm{He}$ overstates his point, however, in asserting that there has been only a single post-Watergate "reform"-public financing of presidential campaigns-and that this reform did nothing to remedy the causes of Watergate. ${ }^{50}$ Each of these assertions appears to be mistaken. First, the financing of both the Watergate break-in and the later cover-up came from the laundered cash raised in great abundance by arm-twisting campaign aides who suggested that official favor would flow from generosity. ${ }^{51}$ Although public financing of elections may not be a panacea for political or electoral abuses, Kurland is simply wrong to ignore the widespread fund-raising abuses that were exposed during the Watergate investigations. Dependence on a few large contributions for political success tends to distort a public official's view of himself as a "public servant"; thus there is a direct link between private financing and Watergate abuses.

47. In 1968, President Nixon barely defeated Senator Hubert Humphrey, winning only $43.4 \%$ of the popular vote (Senator Humphrey captured $42.7 \%$ and Governor George Wallace 13.5\%). 1978 Reader's Digest Alsanac 383. In 1972, however, President Nixon garnered $60.7 \%$ of the popular vote, and his margin of victory over Senator McGovern was a record 18 million votes. Id.

48. For example, the Harris Survey found in October 1972, shortly before the election, that 55\% of those surveyed gave President Nixon a "negative" rating on his "handling of corruption in government." 1 Congressional Quarterl.y, Watergate: Chronology of A CRISIS 29 (1973).

49. See p. 198.

50. See pp. 183-88.

51. See generally B. Woodward \& C. Bernstein, All the President's Men (1974). 
Kurland's pessimism about the extent of post-Watergate reform is misplaced for other reasons. First, Congress has recently passed the Ethics in Government Act of 1978.52 That measure provides a mechanism for court appointment of temporary special prosecutors to investigate and prosecute executive wrongdoing in certain situations. ${ }^{53}$ The legislation also establishes procedures for financial disclosure by top officers and employees of all three branches of government, deals with post-employment conflicts of interest, creates an Office of Government Ethics, and sets up an Office of Senate Legal Counsel..$^{54}$

Second, intensified congressional oversight over the intelligence community has reduced the ability of future administrations to use the intelligence agencies for domestic political purposes, even if it has not entirely eliminated that potential abuse.

Third, Kurland neglects to mention the increasing use of a device that is directly responsive to one of the institutional failings he identifies: the failure of Congress to check executive exertions of power. The device is the legislative veto, by which one House of Congress, or both Houses acting concurrently but without presidential approval, can nullify executive or administrative decisions. In ignoring the legislative veto, Kurland ignores the principal device designed to reconcile congressional responsibility with the practical demands of modern government. The fact that the constitutionality of the legislative veto is seriously questioned ${ }^{55}$ makes Kurland's failure to discuss it all the more startling.

Through the legislative veto, Congress delegates broad authority and discretion to effectuate legislative programs while attempting to reserve the power to decide, on a case-by-case basis, the particular projects, rules, or standards that may conflict with congressional intent. Literally hundreds of federal statutes now contain some type of legislative veto mechanism by which, short of formal legislation, Congress or its members can defer or annul action taken by the executive branch or an independent agency. ${ }^{.6}$ Such statutes are di-

52. Pub. L. No. 95-521, reprinted in 124 CoNG. Rec. H12,285 (daily ed. Oct. 11, 1978).

53. For an analysis of the constitutionality of court-appointed special prosecutors, sce Note, The Proposed Court-Appointed Special Prosecutor: In Quest of a Constitutional Justification, 87 YALE L.J. 1692 (1978).

54. See Ethics in Government Act of 1978, Pub. L. No. 95-521, reprinted in 124 Conc. REc. H12,285 (daily ed. Oct. 11, 1978).

55. See, e.g., Bruff \& Gellhorn, Congressional Control of Administrative Regulation: A Study of Legislative Vetoes, 90 HARv. L. REv. 1369, 1373-74 (1977).

56. A 1976 study found that betweer. 1932 and 1975 Congress enacted 126 statutes containing 183 separate provisions for congressional review, deferral, approval, or disapproval of proposed executive action. See Library of Congress, Legislative Research 
verse; they range from statutes allowing a single committee of one House to overturn a decision, ${ }^{57}$ to statutes requiring the concurrence of both Houses in a resolution of disapproval. ${ }^{58}$ Hardly any significant legislation considered by the Ninety-fifth Congress dealing with federal programs was not the target of efforts by congressmen seeking to reassert legislative prerogatives by tacking on a legislative veto provision. 59

Concern about President Nixon's alleged abuses contributed substantially to the dramatic evolution of this device. Indeed, 87 of the 183 legislative veto provisions passed since 1932 were enacted during or immediately following the Nixon Presidency. ${ }^{60}$ The more recent uses of the legislative veto have not yet been sustained by the courts,

Service, Congressional Review, Deferral and Disapproval of Executive Actions: A Summary and an Inventory of Statutory Authority, reprinted in Congressional Research Service, Library of Congress \& General Accountinc Office, 94tix Cong., 2d Sess., Congressional Oversicht 80 (Comm. Print 1976) (prepared for Subcomm. on Oversight Procedures of Senate Comm. on Gov't Operations) [hereinafter cited as Library of Congress Study. with page citations to Comm. Print].

57. There are 20 such provisions. Id. at 84; see, e.g., National Science Foundation Authorization Act, Pub. L. No. 93-96, § 6, 87 Stat. 316 (1973) (permitting certain committees to veto any allocation of $10 \%$ of NSF funds); Department of Interior Appropriations Act, Pub. L. No. 93-120, 87 Stat. 43 (1973) (requiring approval of certain committees before changing borders of national forests).

58. See, e.g., Education Amendments of 1974, 20 U.S.C. \$ 1232(d) (1976) (allowing both Houses to disapprove any general standard, rulc or regulation promulgated by Secretary of Health, Education, and Welfare as "inconsistent with the Act from which it derives its authority"); Foreign Assistance Act of 1974, 22 U.S.C. $\$ \$ 2441-2443$ (1976) (allowing both Houses to reject President's proposal to provide financial assistance to any country in Middle East).

59. The proposed Federal Trade Commission Act Amendments, H.R. Res. 3816, 95̆th Cong., 1st Sess. (1977), for example, remained stalled in conference for months because the House insisted on the right to disapprove FTC trade regulation rules, and the Senate supported the FTC's objection to this oversight. See 124 CoNG. REc. HI573-79 (daily ed. Feb. 28, 1978).

60. See Library of Congress Study, supra note 56, at 81 . As a direct response to President Nixon's military initiatives in Viet Nam and Cambodia, including some of the "secret bombings" of Cambodia that later became the subject of a possible article of impeachment, see H.R. REP. No. 1305, 93d Cong., 2d Sess. 217-19 (1974), Congress in 1973 enacted 50 U.S.C. $\$ \$ 1547-1548$ (1970 \& Supp. V 1975), superimposing congressional judgment over the President's constitutional powers as Commander-in-Chief. See U.S. ConsT. art. II, $\$ 2$. Following President Nixon's resignation, Congress passed a "Watergate reform"-which Kurland erroneously terms unrelated to Watergate abuses, see pp. 666-67 supra; p. 187-that largely transferred financing of presidential elections to the United States Treasury. See Federal Election Campaign Act Amendments of 1974, Pub. L. No. 93 . 443, 88 Stat. 1263. Included in those campaign finance amendments was a provision for legislative veto of implementing regulations and opinions of the Federal Elections Commission. The legislative veto also figured prominently in another Watergate reform statute, the Presidential Recordings and Materials Preservation Act of 1974, 44 U.S.C. $\$ \S 3315-3324$ (1970 \& Supp. V 1975), by which Congress asserted public ownership-with just compensation to be paid, if necessary-of all of President Nixon's official papers, including the infamous White House Tapes. 
but they show considerable potential for reestablishing Congress as an equal participant in the functioning of modern government.

Although Kurland is sharply critical of the lack of significant postWatergate reform, he offers only a single proposal himself-a proposal, moreover, that is ill-advised. In drawing out his contention that Congress has failed to address the real problems spawning the Watergate abuses, Kurland quotes from a brief statement he submitted to a congressional committee in 1975 on the proposed Watergate Reform Act of $1975 .{ }^{61}$ The bill 62 would have created a permanent "special prosecutor"-a proposal Kurland opposed-and would have created a "Congressional Legal Counsel"-a concept Kurland supported. In addition to representing congressional interests in court, Kurland urged that a new Congressional Legal Counsel be given "the investigatory and prosecutorial function" of handling impeachment inquiries directed at Executive Branch officials. ${ }^{63}$ This recommendation reflects Kurland's support for the increased use of the impeachment procedure, not only for restraining an incumbent President but for monitoring "all executive branch officials," including those "who have already separated themselves or been separated from the service of the nation." 44 Clearly, this proposal represents the height of impracticability and reveals on Kurland's part a lack of appreciation for the realities of constitutional government. Indeed, the principal reason that impeachment had long ago fallen into disuse is that the process is too cumbersome to be effective. ${ }^{65}$ It is plainly irrational

61. Pp. 195-96; see Senate Comm. on Government Operations, Watergate Reorganization and Reform Act of 1975: Perspectives of the American legal and Acadeaic Communities 103-05 (Comm. Print. 1975).

62. S. 495, 94th Cong., Ist Sess. (1975), 121 CoNg. Rec. SI821 (daily ed. Jan. 30, 1975).

63. P. 196. Under Title VII of the 1978 Ethics Act, the Senate Legal Counsel is generally limited to representing Senate interests in court. See 124 Conc. Rec. H12,30I (daily ed. Oct. 11, 1978) (Senate Counsel can defend Senate and institute civil action to enforce subpoena).

64. P. 196.

65. Since 1789 , there have been approximately 60 attempts to have the House impeach federal officials, but only 13 have actually been impeached: one President (Andrew Johnson, 1868), one cabinet officer (Secretary of War Belknap, 1876), one senator (1797), and 10 federal judges (1803-1936). Congressional Quarterly, Guide to Congress 203 (2d ed. 1976). Only four officials (all judges) have been convicted and removed from office by the Senate. $I d$. There have been no impeachments in 42 years. See id. at 208.

Most House impeachments (10 of 13) have involved federal judges. Id. at 203. Prior to the Nixon impeachment inquiry (and apart from the abortive effort by then-Representative Gerald R. Ford to impeach Justice William O. Douglas in 1970, see 116 CoNc. REC. 11,912-14 (Apr. 15, 1970)), the last serious impeachment investigation was in 1936. Congressional Quarterly, supta, at 208. It involved a district judge and was successful. Id.

On September 7, 1978, the Senate passed a bill that would create a special court to force the removal or retirement of judges found guilty of misconduct or suffering from dis. 
to expect the full House of Representatives, functioning like a grand jury, to debate the legal and factual bases for articles of impeachment against an inferior federal officer, or to expect the full Senate to assume the role of an impeachment court to try the articles. Although Kurland is correct in stating that there must be a stimulus to congressional resurgence, it is foolhardy to propose that Congress should revive the current impeachment procedure as a major preoccupation of its time.

\section{A Final Note}

Kurland covers considerable ground in his book, but unfortunately his plow cultivates with more breadth than depth. He is frank enough to describe this book as a collection of essays, rather than a treatise, ${ }^{68}$ and "Watergate" merely provides him with a convenient matrix for diverse reflections. He includes such subjects as the power of congressional inquiry, ${ }^{67}$ the grounds for impeachment, ${ }^{68}$ the 'self-inflated role of the judiciary ${ }^{69}$ the extent of the President's power to

abilities. In explaining the need for the new procedure, the sponsor of the bill, Senator DeConcini, stated:

Historically, Congress has been reluctant to use the drastic measure of impeachment. ... One reason for this reluctance is the fact that impeachment is a complex, slow, and cumbersome process that absorbs an incredible amount of time in both Houses of Congress.... Because it is not used, impeachment has ceased to be a real deterrent to misconduct on the bench.

124 Conc. Rec. S14,745-46 (daily ed. Sept. 7, 1978) (Sen. DeConcini) (discussing S. 1423, 95th Cong., 2d Sess. (1978)).

66. P. ix.

67. Pp. 17-33.

68. Pp. 104-30.

69. E.g., pp. 7-16, 74. Despite the fact that Kurland describes Watergate as "an executive branch disaster," p. 169, he seizes every opportunity to criticize the courts. Unfortunately, his comments on the courts, like much of his book, tend to be highly polemical rather than carefully reasoned. For example, Kurland suggests that the Supreme Court may have acted too hastily in granting the Special Prosecutor's petition for certiorari before judgment by the court of appeals in the Nixon Tapes Case, and in deciding it, amidst the impeachment debate, under the "unfortunately appropriate" title United States v. Nixon. P. 64; see United States v. Nixon, 418 U.S. 683 (1974). Neglected, however, is any reference to the dynamics of this constitutional litigation, a topic on which Kurland surcly could have speculated even in the absence of hard information. The fact is that the Special Prosecutor's Office projected that favorable resolution of the constitutional claims as well as eventual compliance with the Court's mandate would be more likely if the case reached the Court in the context of public attention to the impeachment proceedings. The decision to apply for certiorari before judgment reflected that sense of timing. It also allowed the Special Prosecutor's Office to choose the caption of the case-United States v. Nixon-thus casting the constitutional contest in a framework that vividly simplified the issues. Finally, it provided implicit momentum on one of the key constitutional issues before the Court: the Special Prosecutor's authority to represent the "United States" as a sovercign government in pursuing evidence that "happened" to be in the hands of Richard Nixon the President. This approach was, incidentally, later accepted by the Court. See id. at 697 . 
remove appointees, ${ }^{70}$ the indictability of a sitting President, ${ }^{71}$ and the nature of the modern Presidency. ${ }^{72}$ Because the format is essentially that of the essay, Kurland claims the right to be tentative and provocative, ${ }^{73}$ and that is what this book is. A reader searching for Kurland's traditional depth and firmness will not find it.

Nevertheless, Kurland's book is a worthwhile excursion that identifies dozens of intriguing constitutional questions littering the Watergate landscape. Many of these issues remain unanswered or insufficiently explored, and perhaps the chief value of this work is in reminding us that, although Richard Nixon and his aides may be gone, the constitutional problems of Watergate linger on.

70. Pp. 75-103.

71. Pp. 181-36.

72. Pp. 200-24.

73. See p. ix. 
The Editors wish to dedicate this issue to the memory of Professor Harold Dwight Lasswell of the Yale Law School. 


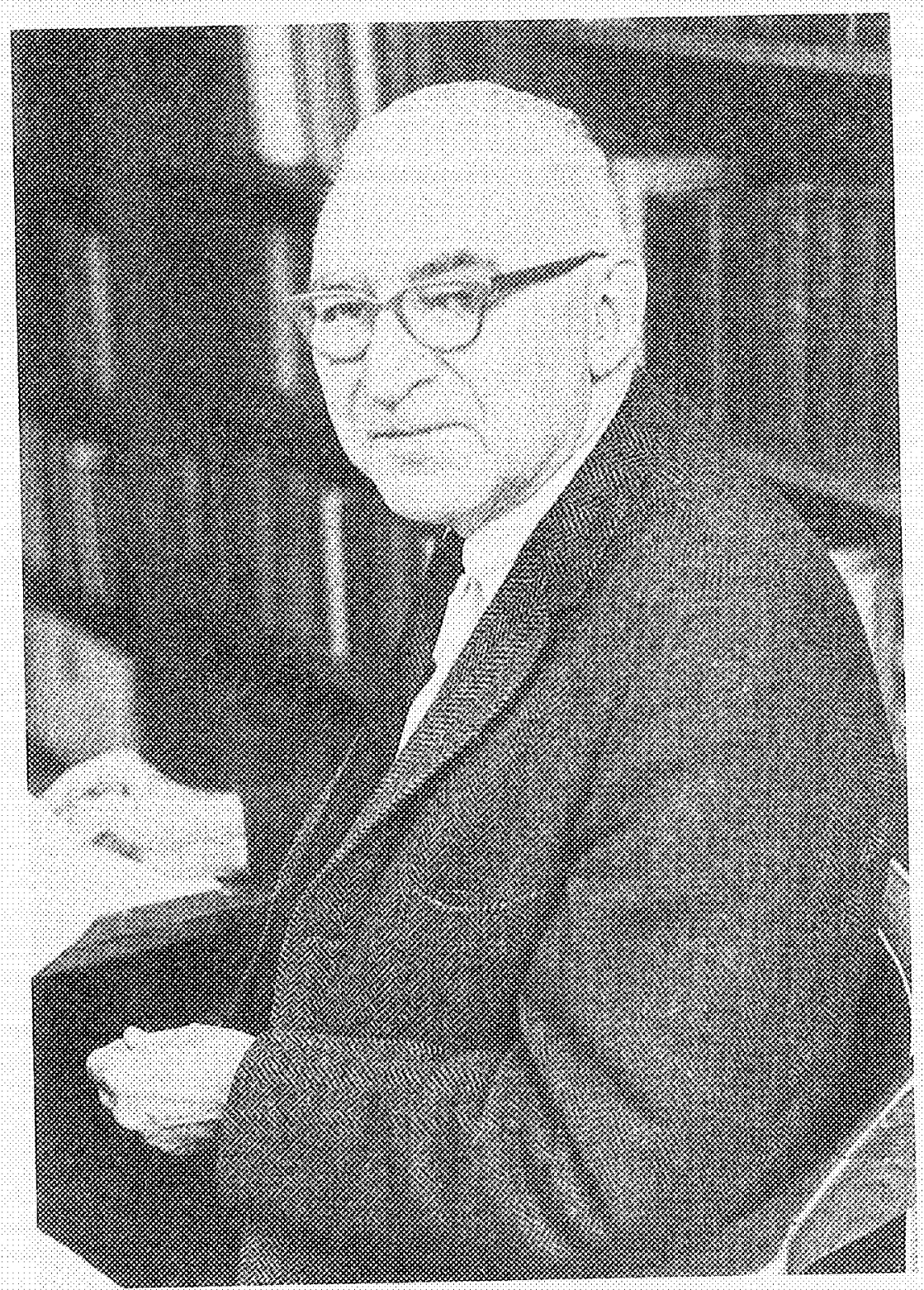

SAROUT DWTGET LASSWELL 